reported by B. Karlemo (Sweden) in a description of methods for production of geophysical maps.

At a joint evening meeting with the Danish Geophysical Society, D. Malmqvist (Sweden) gave a review of electrochemical ore-prospecting methods and emphasized the utility of this prospecting method. The 'polarization provoquée' method proposed by Schlumberger about forty years ago seems to be very suitable, especially in cases dealing with disseminated ores, and Mr. Malmqvist demonstrated some survey examples from northern Sweden.

The chairman, H. Brækken (Norway), introduced at the business meeting the very important problem of education of mining geophysicists. The meeting appointed a committee (Brækken, Werner and
Tengstrøm (Sweden)) to consider the different points and to report at the next meeting.

With regard to the planning committee for the third meeting, which is contemplated within two years, the meeting appointed B. Tornqvist as chairman (Sweden), and H. Brækken, M. Puranen (Finland), and S. Saxov (Denmark) as members.

In all, the second Nordic Meeting for Mining Geophysics proved to be most successful, the attendance being about 100 per cent higher than at the first meeting at Boliden, Sweden, during November $7-9,1956$; the discussions were many and the opinion of the meeting strongly supported the arrangements for future meetings and co-operation in common problems.

SVEND SAXOV

\title{
THE MEDICAL RESEARCH COUNCIL
}

\section{REPORT FOR THE YEAR 1957-58}

\begin{abstract}
$\mathrm{T}$ HE recent report of the Medical Research Council for the year 1957-58, prepared by the Committee of Privy Council for Medical Research, adopts once more the form now used for several years (Cmnd. 792. Pp. viii +288. (London: H.M. Stationery Office, 1959.) 13s. net). Instead, that is to say, of giving detailed accounts of all the researches in progress, it gives articles based on certain aspects of the Council's very varied programme, the intention being to deal, once every few years, with all the important fields of research undertaken by the Council's staff. These articles are also published separately under the title "Current Medical Research" (Pp. iii +46. (London : H.M. Stationery Office, 1959.) 3s. 6d. net).

In this publication and also in the report itself we are given a description of the Council's Laboratory in Gambia, West Africa. As part of its contribution to research in tropical medicine, the Council maintains three laboratories, in Uganda, Jamaica and Gambia, respectively, and that in Gambia here described is the oldest and largest. Unlike the others, it is self-contained and is not attached to any local institution. Situated at Fajara, it was originally part of the Council's Human Nutrition Research Unit in London, but its scope has now been widened to include research, not necessarily on tropical medicine, but in other fields as well. Many research workers use its increased facilities-cardiologists, chest and other specialists, pædiatricians, public health workers and others. The centre is visited by many research workers from Britain and has lately been used by a team representing the Council's Research Group on trachoma, a cause of blindness which, because of the menace it is, is
\end{abstract}

engaging the attention of research workers all over the world. This centre is also developing research on the hyperendemic malaria of the Gambia region, a region which offers special facilities for work of this kind, and this is discussed in a separate article in the report. Much of it is done at Keneba, and to facilitate communication between Keneba and the laboratories at Fajara a radio-telephone has been set up, and the Wellcome Trust has generously provided a cabincruiser, The Lady Dale, which can also be used as a floating laboratory.

As well as the article just mentioned on the hyperendemic malaria of the Gambia area, the report includes articles on the remarkable work being done by members of the Council's staff on intracellular organelles and on the enzymes contained in them. Other articles discuss the work being carried out on the viruses of trachoma and inclusion blenorrhœea, the types of the bacillus that causes Sonne dysentery, the cancer-producing viruses and their immunology, the ultra-microscopic analysis of body fluids, the performance of coal miners in hot atmospheres, the fertilization of the mammalian egg and the rehabilitation of schizophrenic people. Another article of interest discusses research in general medical practice, a line of work which is much to be encouraged. An innovation in the report is the introduction of two photographs, one of which shows The Lady Dale, and two line illustrations.

For the rest the report contains its usual features. Brief summaries of the work of each of the Council's research units are given, together with the names and. research addresses of the Council's many workers. A long bibliography lists the varied work that these workers have published.

G. LAPAGE

\section{COMPARISON OF RAIN-GAUGES}

$\mathrm{T}$ HE measurement of precipitation is a difficult problem because of the great variations in the nature of the precipitation and of the effects of wind eddies around the gauge. The radii of liquid drops and their rates of fall range from $0.2 \mathrm{~mm}$. at $0.7 \mathrm{~m}$. $/ \mathrm{sec}$. of drizzle to $5 \mathrm{~mm}$. at $8 \mathrm{~m}$. $/ \mathrm{sec}$. of the heaviest thunderstorm rain, while the speed of the wind around the gauge can vary over a somewhat greater range. Solid precipitation is even more difficult to measure. It ranges from fine snow to heavy fast-falling hail-stones and may at low temperatures completely choke the gauge if, as is usual, no heating 